\title{
Analysis of Blank Spot Data in the Communication Area with the Geoprocessing Method in Southern West Java
}

\author{
R. A. E. Virgana*, Dan Dani Hamdani \\ Department of IS, Faculty of Engineering, Widyatama University, Indonesia
}

Copyright $\odot 2019$ by authors, all rights reserved. Authors agree that this article remains permanently open access under the terms of the Creative Commons Attribution License 4.0 International License

\begin{abstract}
In this study, the southern part of West Java Province, especially along the southern coastline in Cianjur Regency (in part), Garut Regency, Tasikmalaya Regency, and Pangandaran Regency, has tremendous potential. For the southern path of West Java alone, $417.4 \mathrm{~km}$ connected, from the start of Sukabumi Regency to the west of West Java, to Pangandaran Regency in the east of West Java, the potential and uniqueness of almost all new roads along the southern path of West Java show the extraordinary beauty and natural resources of West Java. Almost all roads on this track it is very neat, new and sturdy bridges. The residents along the southern coastline of West Java have begun to be busy in fishing industries, farms, timber industries, and other industries. But the means of cellular communication, especially along this route, which was the object of research in this study, signals exist and do not exist. There are some $2 \mathrm{G}$, some $3 \mathrm{G}$, and $4 \mathrm{G}$ will begin to appear when entering Big cities such as Pameumpek and Pangandaran. This research is expected to be able to map all blank spot areas, cellular operator signal services, especially on the new road along the coast in South West Java to the east from the starting point east of Cianjur Regency to the west of Pangandaran Regency. Desimination tools using geographic information systems, the method used by geoprocessing will overlay regional maps, satellite maps, and cellular operator BTS signal maps.
\end{abstract}

Keywords GIS, Geoprocessing, BTS, Blank Spot

\section{Introduction}

The Cianjur Regency with an area of $3,840 \mathrm{~km}^{2}$, Garut Regency 3,074 km², Tasikmalaya District 2,551 km², Pangandaran Regency $1,010 \mathrm{~km}^{2}$ is a very wide area. The four districts have new roads or new through roads along its southern coastline, some of which already exist in the south coast roads, and some of which have just been created and connected after there is a national program of alternative road routes along the southern coast of Java.

As seen in Figure 1, a blank spot survey path of BTS (Base Transceiver Station) signals in this study, is limited to only those lines.

The limitation of the research path is due to limited time and costs, and limit research problems, so only the south coast of West Java, from Cianjur Regency (part of the region) in the West (the starting point of Balegede District), to Pangandaran Regency in the east (District endpoint Pangandaran). Whereas, the area to the west end of West Java province, such as Sukabumi Regency (area 4,145 km2) and parts of other Cianjur regencies to the west, were not surveyed, because the two regions were very wide, and were 2 districts in the widest area in West Java. The residents along the southern coastline of West Java have begun to be busy in scale fishing industries, scale farms, timber industries and other industries along this route. But the means of cellular communication, especially along this route, signals exist and do not exist. There are some 2G, some $3 \mathrm{G}$, and $4 \mathrm{G}$ will begin to appear when entering Big cities such as Pameumpek and Pangandaran.

This research is expected to be able to map all blank spot areas, especially the position of BTS in a village area, which later in the geoprocessing process. It is found BTS point positions will be intersected with the village area, so that villages that do not have a signal service provider BTS also simulate of operator signal strength maps. This research has been carried out a survey specifically on the new coastal road along the southwest to east along $300 \mathrm{~km}$, from the starting point of the BTS data search, starting from the east of Cianjur Regency (Balegede District), to the west of Pangandaran Regency (Kec. Pangandaran), desimination tools using geographic information systems, geoprocessing methods that will overlay maps of regions (villages), satellite maps, and signal maps of cellular BTS operators. 


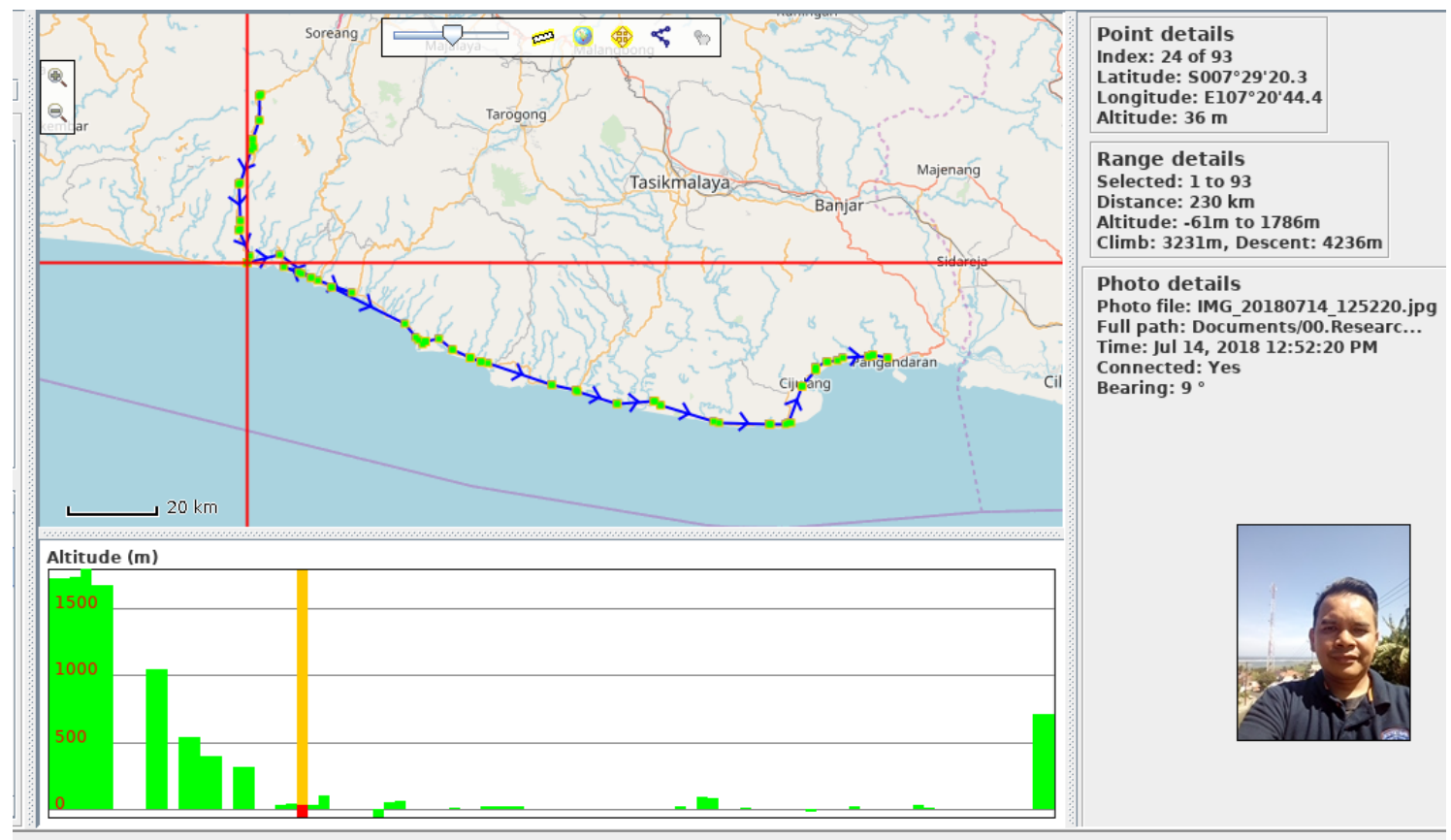

Figure 1. Track tracking Research in blank spot area

\section{Literature Review}

\subsection{Information and Communication Technology Services}

Information and communication technology infrastructure (ICT) has become one of the basic infrastructure needed parts of the facilities and infrastructure that must be provided to support the acceleration of development in the region. The limitations and challenges are different for each region in West Java, especially the southern part [1].

With the uneven distribution of ICT infrastructure, this has created a large digital divide (regional divide) between regions in West Java, especially the southern part, where the ICT infrastructure has only been built with the focus of certain regions that have better economic value, compared to other regions in West Java [2]. In order to overcome this problem, it is necessary to develop infrastructure that focuses more on regional development efforts [3].

It is necessary to identify the identification of blank spot areas in ICT service areas, especially in the southern part of West Java province, in order to identify the conditions of readiness and availability of ICT infrastructure in the southern part of West Java. The information generated is expected to be able to assist the process of deploying ICT infrastructure in the regions by utilizing available resources, including through collaboration with ICT infrastructure service providers [4] [5].

\subsection{Maps, GIS, QGIS, and WebGIS}

The map is an illustration of the geographical area. The surface of the earth that is presented in various different ways, starting from conventional maps printed with digital maps which can be updated with new thematic maps and can add details of other geographic information [6]. In thematic mapping [7], data are visualized based on certain categories with spatial concepts. The spatial concept comes from several spatial data. Geographic Information System (GIS) is a computer system based on information systems that is used to provide digital forms and analysis of the geographic surface of the earth [8]. Quantum GIS or better known as QGIS is an open source geographic information system that is licensed by the GNU General Public License, and supports various vectors, raster and database formats and functionalities [9]. QGIS Server is the back end of the GIS desktop for visualizing the GIS web map [10]. Web GIS is a type of distributed information system, which consists of at least a server and client, where the server in question is a GIS server and the client in question is a web browser [11].

\section{Research Methods}

The research process consists of a series of actions or steps needed to effectively carry out research and the desired sequence of steps. To avoid problems arising from the research process, procedures that were previously calculated are needed.

According to C. R. Kothari [12], the detailed steps of the process to provide procedural guidance that are useful in the research process are as follows: 


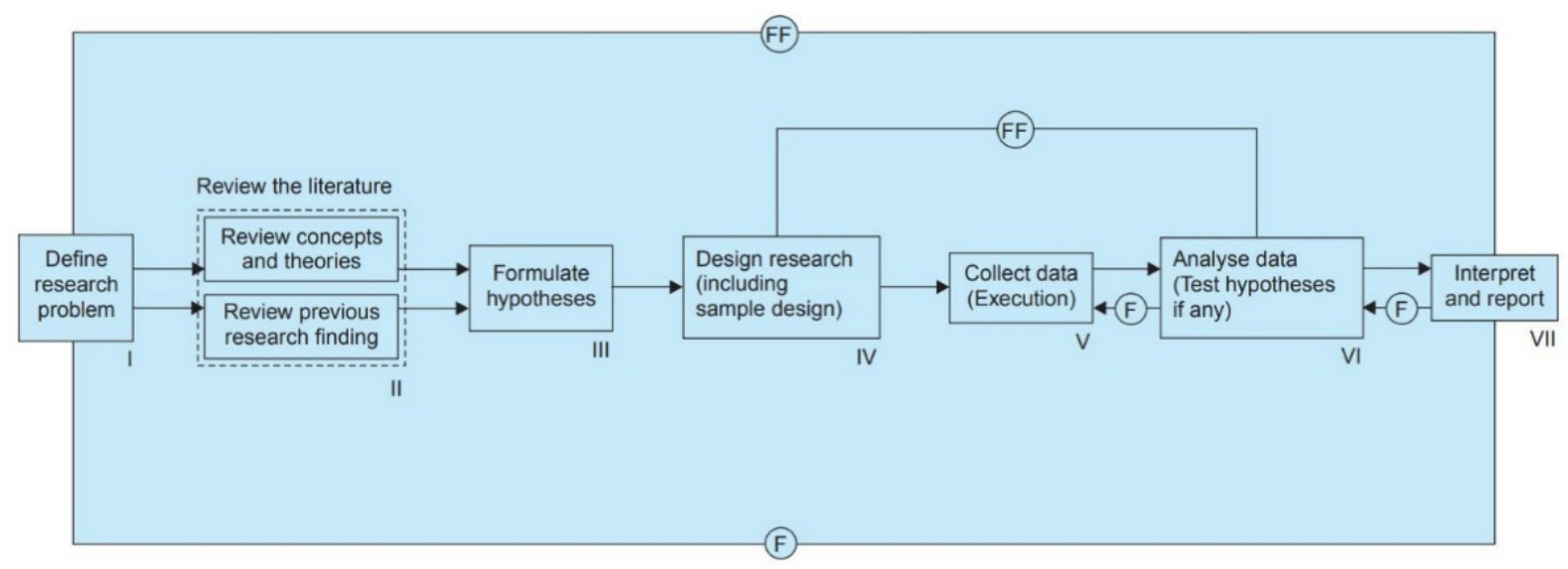

Figure 2. The research process in the flow chart [12]

\section{Results}

\subsection{Formulating the Research Problem}

1. How to examine the possibility of cellular operator signal spot blank areas in southern West Java?

2. How to get BTS (Base Transceiver Station) tower data, by conducting a survey with war driving techniques, along the research path, from the starting point of BTS data search, starting from the east of Cianjur Regency (Balegede District), to the west of Pangandaran Regency (Kecamatan Pangandaran)?

3. How to process BTS (Base Transceiver Station) tower data with geoprocessing techniques, to sort out villages that do not have them?

4. How to disseminate the results of processing the data in the form of geographic information systems?

\subsection{Extensive Literature Survey}

Researchers have conducted a literature survey, especially the literature on the importance of the distribution of telecommunications in a country determines the progress and acceleration of development of a region, southern West Java, according to researchers the acceleration of development lags far behind the northern region of West Java [13].

\subsection{Development of Working Hypotheses}

Development in southern West Java is very far behind the development of West Java in the north. Many factors make this region far behind other areas in West Java, one of which is road access. First road access to some areas of South West Java is partial, separated and is not connected to each other along the path of this south coast of West Java, which is famous for its beauty. Then, the geographical factor, the area of South West Java is very unique, which is a simple thing that we can note. If we are in a position on one of the beaches in the area of South West Java, we can see the landscape that directly rises from the coast to the mountains in Java South West. Even in some points uphill towards the mountain from the shoreline, we can see it like in the Cidaun and Rancabuaya regions. Maybe these geographical factors are why the pass through the south coast of West Java has only been completed for several years, even though Indonesia has long been independent, so that there were no physical roads, especially airways (telecommunications).

Praise be to God. Now the physical road is translucent and connected. It runs smoothly with hundreds of sturdy iron bridges, although there is at some point a long bridge that can only be passed by one vehicle. The community has been very happy, staying a telecommunication facility that seems to have not been held as a whole in the southern part of West Java, in contrast to the physical road which is the government's obligation to deploy, for airways (telecommunications) cellular operators who have obligations, but no cellular operators the government. Cellular operators will consider return on investments (roi), when they will build BTS towers along the south coast of West Java, although usually red plate operators such as Telkomsel usually hold base stations in remote areas such as South West Java.

So from this explanation, this simple research is important for photographing the distribution of telecommunications in southern West Java, especially the object of research in this study, only along the new road along the southern coast from Cianjur District (Balegede District) to Pangandaran Regency ( Pangandaran Subdistrict) along $300 \mathrm{KM}$, although researchers are aware of the limitations of time, cost, and tools. The results of the study will not be very accurate, because of the breadth of this research area. But hopefully in general, it can describe the potential of telecommunications in this southern West Java.

\subsection{Preparing the Research Design}

In accordance with the research title, "Analysis of Blank 
Spot Data in the Communication Area with the Geoprocessing Method in Southern West Java", the main variable in this study is the blank spot communication area analysis in southern West Java, using secondary variables to influence the main variables namely using the geoprocessing method, so that the desimination results can be obtained in the form of geographic information systems (GIS).

This research uses mixed method, qualitative and quantitative, for qualitatively how to answer the problem formulation about the hypothesis of the existence of blank spot areas in the southern part of West Java. Then the results will be answered descriptively and in forms of geographic information (thematic maps). To support these qualitative results, quantitatively the BTS (Base Transceiver Station) signal point distribution data will be overlaid with village area data, then geoprocessing. The result is quantitative data of rural areas in southern West Java that do not exist. The BTS.
This study requires secondary and primary data. For secondary data, researchers will get the survey literature. And for primary data, researchers will conduct war driving (looking for operator signals) along the new road along the south coast of West Java, using vehicles along the $300 \mathrm{KM}$ starting from the search point in Cianjur Regency (Balegede District), passing through Garut Regency (Pameumpek District), passing Tasikmalaya Regency (Cipatujah District), up to the last point in Pangandaran Regency (Pangandaran District). The results of the primary data, the researchers will process and produce geographic information about the possibility of a blank spot area in southern West Java.

\subsection{Determining Sample Design}

The primary data obtained is the population data point BTS (Base Transceiver Station), the data sample is as follows:

Table 1. Following is an example of Sample BTS (Base Transceiver Station) data

\begin{tabular}{|c|c|c|c|c|}
\hline wkt_geom & CLNT_NAME & SERVICE & SUBSERVICE & STN_NAME \\
\hline $\begin{array}{c}\text { POINT(107.35680555560000471 } \\
-7.26508333329999978)\end{array}$ & XL AXIATA, Tbk & Land Mobile (public) & GSM/DCS & $\begin{array}{c}\text { 2/A044 } \\
\text { BALEGEDE_CIANJUR }\end{array}$ \\
\hline $\begin{array}{c}\text { POINT(107.3578888890000692 } \\
-7.2571111111000004)\end{array}$ & INDOSAT,PT(PERSERO) & Land Mobile (public) & GSM/DCS & $11 /$ BALEGEDE \\
\hline $\begin{array}{c}\text { POINT(107.33275000000000432 } \\
-7.40455555560000001)\end{array}$ & TELKOMSEL,PT & Land Mobile (public) & GSM/DCS & $\begin{array}{c}1 / \text { CJR072_ } \\
\text { KPLASARIMG }\end{array}$ \\
\hline
\end{tabular}

\subsection{Collecting the Data}

In collecting data, a survey was conducted in war driving (search for operator signals through vehicles), from Cianjur Regency (Balegede Sub-district) to Pangandaran District (Pangandaran Sub-district), seen in Figure 1., is a survey path that has been carried out.

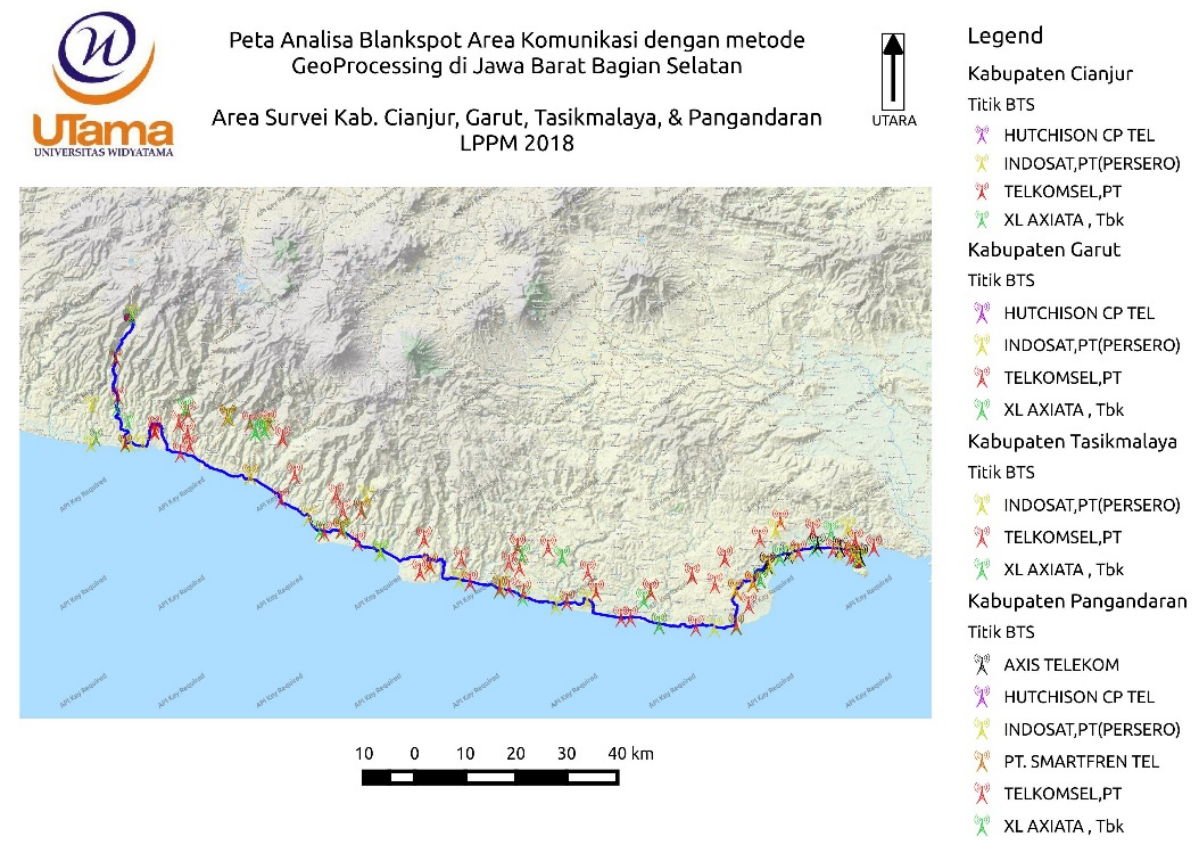

Figure 3. Distribution of BTS along the Survey Path on the South Coast of Western Java 
Table 2. Sample of BTS (Base Transceiver Station) data points with Observation Photos

\begin{tabular}{|c|c|c|c|}
\hline COORDINATE & CLNT_NAME & STN_NAME & PHOTOS \\
\hline $\begin{array}{c}\text { POINT(107.3568055556000047 } \\
1 \text {-7.26508333329999978) }\end{array}$ & XL AXIATA, Tbk & $\begin{array}{c}\text { 2/A044 BALEGEDE_ } \\
\text { CIANJUR }\end{array}$ \\
& & & \\
POINT(107.3446444444000036 & INDOSAT,PT \\
(PERSERO) -7.4885277777999999$)$ & 6/DCS_CIDAUN & & \\
\hline
\end{tabular}

\subsection{Execution of the Project}

The methodology for conducting the research used in this study is how data is collected, both non-spatial data (BTS-Base Transceiver Station), and spatial data on the territorial map of villages, sub-districts, districts and provinces. Then the data will be processed geoprocessing, there are processes of sorting / data intersection / intersection, then the data is visualized in GIS tools [14] [15], as shown in Figure 4. The following:
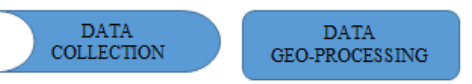

\section{OUTPUTVISUALISASIGIS}

Figure 4. ICT Analysis Method blank spot Southern West Java Area

The end of the output / analysis results, in the form of the map display results, including exporting it to the desired format such as in the form of tables, graphs, reports, maps and so on [16] [17]. The software, tools used by researchers are Quantum GIS, an open source GIS software tool that has completely geoprocessing tools [18].

\subsection{Data Analysis}

Data analysis, first move the BTS (Base Transceiver
Station) point data to a spatial points map, the results look like Figure 3., all BTS points of all operators are pointing according to the position of latitude, longitude for each BTS point.

Then preparing a spatial map of polygons in the villages, sub-districts and districts, this map is only produced by one body in our country, namely the Geospatial Information Agency of Indonesia (BIG).

Then, spatial points map and spatial polygon map of the region, the geoprocessing process is carried out to produce infographics, spatial points (point) BTS (Base Transceiver Station) data are overlaid with spatial polygon maps of villages, sub-districts and districts, then intersect (geoprocessing). ), to get villages that do not have BTS towers.

Data analysis, first move the BTS (Base Transceiver Station) point data to a spatial points map, the results look like Figure 3., all BTS points of all operators are pointing according to the position of latitude, longitude for each BTS point.

Then preparing a spatial map of polygons in the villages, sub-districts and districts, this map is only produced by one body in our country, namely the Geospatial Information Agency (BIG). The overall results can be seen in Figure 5. 


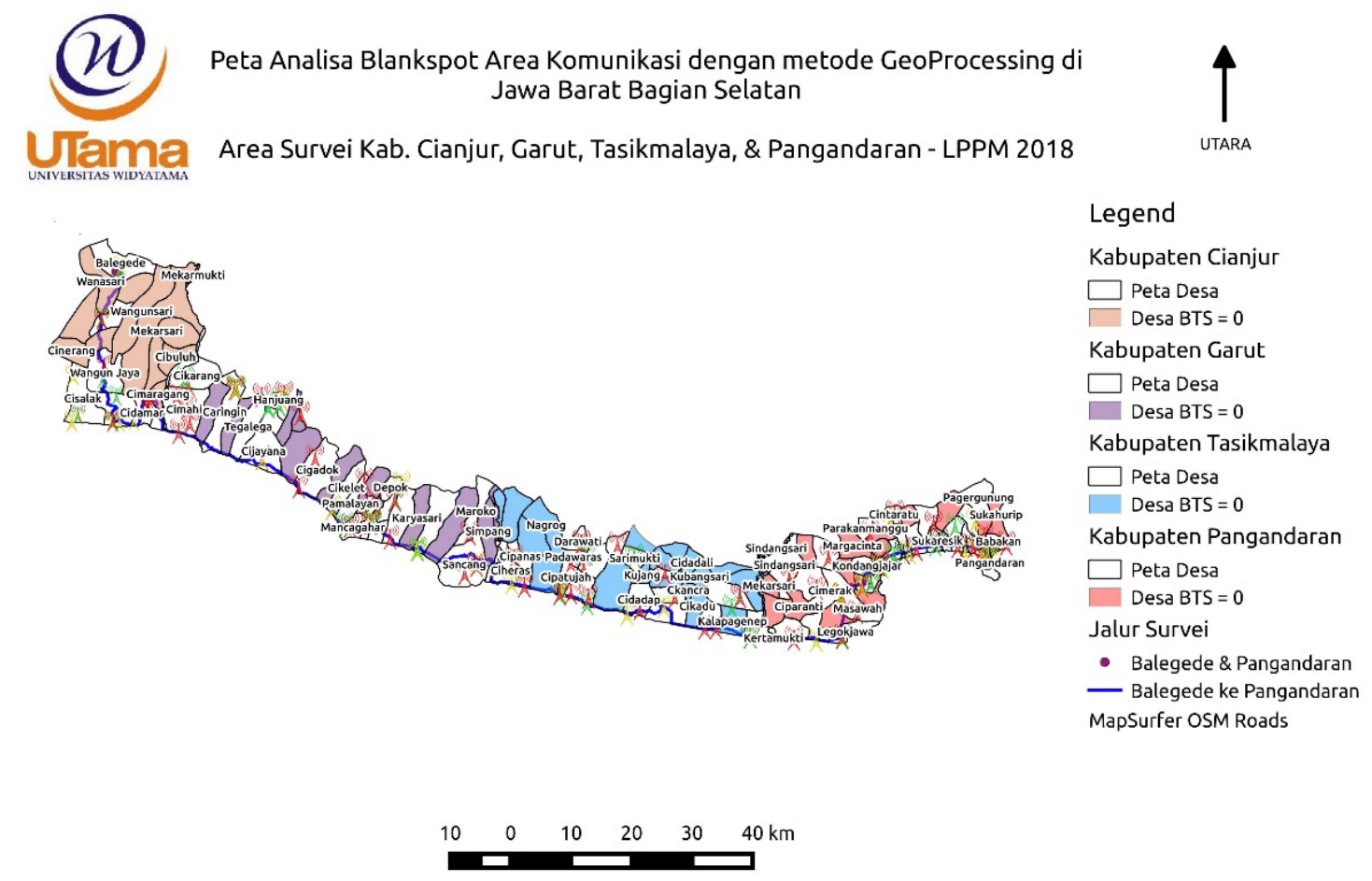

Figure 5. Distribution of BTS and Villages that do not have BTS

\subsection{Hypothesis}

The initial hypothesis of the researchers suspected the existence of a blank spot area in southern West Java. In this chapter, the researcher will describe the GIS methodology geoprocessing, do geographical comparisons ranging from radio distribution, operator BTS, district/ village administrative area, and operator signal strength, in terms of this is especially the operators of XL, Telkomsel and Indosat [19].

\subsection{Generalizations and Interpretations}

The joint interpretation process of the summary of the blank spot area in the southern part of West Java, especially along the southern coastline, will be discussed further in next papers - Analysis of 3 Signal Operators in South West Java.

\subsection{Preparation of the Final Report}

The process of finalizing the final report, thank God, the researchers have done. This report is the final result of this study, and hopefully it is useful for those who read it.

\section{Conclusions and Suggestions}

Alhamdulillah, Thanks God for all His mercy and love. The researchers concluded that there is a possibility of the blank spot signal cellular operators in southern West Java, especially in the mountainous areas in the southern part of
Cianjur Regency, areas with many canyons, valleys, deep ravines and ravines, making signals exist and not in some locations in this area. Along the southern coast of West Java to the east, from South Cianjur Regency to Pangandara Regency, the overall signal exists, but the relative signal strength for each location point.

BTS (Base Transceiver Station) tower data have been obtained, along the research path, from the starting point of the BTS data search, starting from the east of Cianjur Regency (Balegede District), to the west of Pangandaran Regency (Kec. Pangandaran).

BTS tower data (Base Transceiver Station) has been processed with geoprocessing techniques, to sort out villages that do not have BTS and also simulate the operator signal strength for each of these study areas.

The suggestions that the researcher can convey are that the southern part of West Java is one of the pearls in this province that has not been explored extensively. The road infrastructure which has begun to be good, should be supported by better telecommunications infrastructure. More detailed research areas can still be done by other researchers, especially in rural areas far from the main road along the southern coastline in south West Java.

\section{REFERENCES}

[1] Sangwan, A., Kumar, G., \& Gupta, S. (2016). To Convalesce Task Scheduling in a Decentralized Cloud Computing Environment. Review of Computer Engineering Research, 
3(1), 25-34.

[2] Ani Wilson, Ugwunta David, Eneje Beatrice, Okwo Mary (2014), "How Telecommunication Development Aids Economic Growth: Evidence From ITU ICT Development Index (IDI) Top Five Countries For African Region”, International Journal of Business, Economics and Management.

[3] Michael Minges (2016), "Exploring the Relationship Between Broadband and Economic Growth", World Development Report - Digital Dividends.

[4] Dr. Mulyanto Darmawan (2011), “Sistem informasi Geografi (SIG) dan Standarisasi Pemetaan Tematik", Kajian Standarisasi Pemetaan Tematik Pertanahan.

[5] Eddy Prahasta (2005), “Sistem Informasi Geografis”, C.V. Informatika, Bandung.

[6] D. Carter and I. Agtrisari (2003), "Desain dan Aplikasi SIG”, PT Elex Komputindo [7] F. Ormeling (2018), "Thematic maps", diakses pada tanggal 1 September 2018, URL: https://icaci.org/files/documents/wom/06_IMY_WoM_en. pdf.

[7] E. Prahasta (2002), "Konsep-konsep Dasar Sistem Informasi Geografis”, C.V. Informatika, Bandung

[8] QGIS (2018), “QGIS - The Leading Open Source Desktop GIS”, diakses pada tanggal 5 September 2018, URL: https://qgis.org/en/site/about/index.html.

[9] QGIS (2018), “QGIS User Guide”, Open Source Geospatial Foundation (OSGeo).

[10] ArcGIS (2018), “About Web GIS”, diakses pada tanggal 5 September 2018, URL: https://enterprise.arcgis.com/en/ser ver/latest/create-web-apps/windows/about-web-gis.htm.

[11] C. R. Kothari (1990), "Research Methodology Method \& Techniques (Second Revised Edition)", New Age International, New Delhi.

[12] Badan Pusat Statistik (BPS) (2016), "Provinsi Jawa Barat Dalam Angka”, Badan Pusat Statistik (BPS) Jawa Barat, Bandung.

[13] Bouazza, M., Amara, K., Zidour, M., Tounsi, A., \& Adda-Bedia, E. A. (2015). Postbuckling Analysis of Functionally Graded Beams Using Hyperbolic Shear Deformation Theory. Review of Information Engineering and Applications, 2(1), 1-14.

[14] Burrough P. (1986), "Principle of Geographical Information System for Land Resources Assesment", Claredon Press, Oxford.

[15] Stephanie Rogers, Patricia Vivas (2014), “A study on the use of Geographical Information Systems (GIS) for the creation of addressing systems”, Universal Postal Union.

[16] Adebayo, A., \& Oluwadare, B. S. (2014). Corrosion of Steels in Water and Hydrogen Sulphide. Review of Industrial Engineering Letters, 1(2), 80-88.

[17] Retno Astrini, Patrick Oswald (2012),”Modul Pelatihan Quantum GIS”, GIZ Decentralization as Contribution to Good Governance (DeCGG).

[18] Jabarullah, N. H., Verrelli, E., Gee, A., Mauldin, C., Navarro,
L. A., Golden, J. H., \& Kemp, N. T. (2016). Large dopant dependence of the current limiting properties of intrinsic conducting polymer surge protection devices. RSC Advances, 6(89), 85710-85717. 